\title{
ECONOMIC POLICIES AND TECHNOLOGY INNOVATION
}

\author{
https://doi.org/10.4215/rm2019.e18025

\begin{abstract}
Mateus Boldrine Abrita ${ }^{*}$ - Ricardo Dathein ${ }^{b}$ - Angelo Rondina Neto ${ }^{c}$
\end{abstract} \\ Luma de Oliveira $d$
}

(a) Dr. in Economia. Professor State University of Mato Grosso Mato Grosso do Sul, Campo Grande (MS), Brazil. ORCID: https://orcid.org/0000-0002-3327-4556. LATTES: http://lattes.cnpq.br/3938314040854246.

(b) Dr. in Economia. Professor Federal University of Rio Grande do Sul, Porto Alegre (RS), Brazil.

ORCID: https://orcid.org/0000-0002-7301-2788. LATTES: http://lattes.cnpq.br/3376455208553048.

(c) Dr in Economia. Professor State University of Maringá, Maringá, (PR), Brazil.

ORCID: https://orcid.org/0000-0002-2137-0751. LATTES: http://lattes.cnpq.br/1514169258016616.

(d) Dra. in Economia. Professor State University of Ponta Grossa, Ponta Grossa (PR), Brasil.

ORCID: https://orcid.org/0000-0002-7134-0673. LATTES: http://lattes.cnpq.br/2785884791944921.

\author{
Article history: \\ Received 12 August, 2019 \\ Accepted 11 October, 2019 \\ Publisher 20 November, 2019
}

\section{(*) CORRESPONDING AUTHOR}

Address: UEMS - Avenida Dom Antônio Barbosa, s/n, CEP: 79115898, Campo Grande (MS), Brasil - Tel.: (+55 67) 3901461

E-mail: mateusabrita@hotmail.com

\begin{abstract}
Considering important studies on innovations such as those by Schumpeter (1982), Dosi (1982) and, especially, Mazzucato and Penna (2016), in which they analyzed Brazil's system of innovations, pointing out the macroeconomic regime as a major weakness, this paper's objective is to analyze and discuss the relationships between selected macroeconomic variables (such as exchange, interest and inflation rates and industrial production) and innovations in Brazil. For this, a vector of error correction (VEC) model is estimated. The results found a negative relationship production) and innovations in Brazil. For this, a vector of error correction (VEC) model is estimated. The results found a negative relationship innovation itself, and a negative relationship with a short-term exchange rate depreciation immediately after the shock but becoming positive after a few periods.
\end{abstract}

Keywords: Innovation; Economic Policies; Território brasileiro.

\section{Resumo / Resumen}

\section{POLÍTICA ECONÔMICA E INOVACÕES TECNOLÓGICAS}

Considerando importantes trabalhos sobre inovações como os de Schumpeter (1982), Dosi (1982) e sobremaneira Mazzucato e Penna (2016), no qual, analisaram o sistema de inovações do Brasil e apontaram como uma grande fraqueza o regime macroeconômico, este trabalho tem por objetivo analisar e discutir as relações entre variáveis macroeconômicas selecionadas, como câmbio, juros, inflação e produção industrial e as inovações tecnológicas no Brasil. Para tal, estima-se um modelo de séries temporais de vetor de correção de erros (VEC). O resultado encontrado é uma relação negativa entre inovação e as variáveis macroeconômicas juros e inflação, uma relação positiva com a produção industrial e com a própria inovação e uma relação sutilmente negativa, com uma depreciação cambial no curto prazo, e positiva após passar alguns períodos.

Palavras-chave: Inovação. Política econômica. brazilian territory.

\section{POLÍTICA ECONÓMICA E INNOVACIONES TECNOLÓGICAS}

Considerando importantes trabajos sobre innovaciones como los de Schumpeter (1982), Dosi (1982) y especialmente Mazzucato y Penna (2016), que analizaron el sistema de innovación de Brasil y concluyeron que el régimen macroeconómico era una gran debilidad, este trabajo tiene por objetivo analizar y discutir las relaciones entre variables macroeconómicas seleccionadas, como cambio, intereses, inflación y producción industrial y las innovaciones tecnológicas en Brasil. Para ello, se estima un modelo de series temporales de vector de corrección de errores (VEC). El resultado encontrado es una relación negativa entre innovación y las variables macroeconómicas de interés e inflación, una relación positiva con la producción industrial y con la propia innovación y una relación sutilmente negativa, con una depreciación cambiaria a corto plazo, y positiva después de pasar algunos períodos.

Palabras-clave: Palabras clave: La innovación. Política económica. Territorio brasileño. 


\section{INTRODUCTION}

A major challenge for Brazil is to promote a productive structural change, in order to encourage sectors and products with high technological content, high-income elasticity of domestic and foreign demand and increasing returns to scale, which have positive feedback in the economy, as well as gains in productivity and growth. These factors can favor the formation of a virtuous growth and development cycle.

In this manner, the existence of an innovative environment that helps the productive structure to stay close to the global technological frontier is important. Analyzing innovations, Dosi (1982) argues that economic conditions play an important role and interact with the process of selecting new technologies, with their development, and with their obsolescence and substitution. With this base, Mazzucato and Penna (2016) analyze Brazil's system of innovation and point to the macroeconomic regime as a great weakness. Therefore, having favorable macroeconomic conditions for innovation, although not a sufficient condition, is a very important one to aid the innovative process.

The objective of this paper is to investigate the relations between technological innovations and macroeconomic variables in order to observe whether they have positive or negative relationships. As our hypothesis, we expect negative relations of innovation with interest and inflation and positive relation with industrial production, exchange rate (depreciation) and with innovation itself.

The paper has four more parts besides this introduction. Initially, it presents a literature review, addressing the importance of technology for economic development, the relationships between shortand long-term macroeconomic policies, as well as a discussion about macroeconomic variables in Brazil and innovation. Later, a time-series econometric model will be estimated with the purpose of investigating the relations between macroeconomic variables and innovations. In the end, the final considerations are presented.

\section{Importance of technology for development and short and long-run policies}

Schumpeter (1982) notes that the capitalist system presents, in its nature, a form or method of economic change - i.e., it is never stationary. The fundamental impulse that drives and maintains the movement of the capitalism derives from the new consumer goods, the methods of production or transportation, the new markets and the new forms of industrial organization that the capitalist enterprise generates. In this scenario, technological innovations gain a special highlight. A qualitative change in the transformation of the productive structure of a given region may be closely related to the economic development of that region.

The studies of Dosi et al. (1988) and Dosi, Pavitt, and Soete (1990) delimit the concepts of dynamic and static efficiencies despite the differentiation in the allocation of productive resources of each type of efficiency. The static allocative efficiency, or Ricardian, considers that the productive structure must be oriented to the sectors and products that have comparative advantages of cost, given the factor endowments in relation to international trade. This approach is said to be static since it does not incorporate the change of process over time - thus, a particular country or region will always be doomed to produce a specific product and be restricted to that sector.

However, dynamic efficiency considers that the productive process itself can have positive effects for productivity and growth over time, as it dynamically directs its productive structure to the sectors with the highest technological content and with a greater income elasticity of internal and external demand. This is because dynamic efficiency considers that these sectors and products are constantly changing and that the productive structure, therefore, will also present a dynamic efficiency in time.

When an economy orientates its productive structure to sectors and products with the possibility of having greater income elasticities of domestic and foreign demand, achieving positive effects of productivity, production, employment and eliminating possible restrictions from the balance of payments, it is said that it is in the "Keynesian efficiency standard". When an economy directs its productive structure to more innovative sectors, which have high technological contents and present high levels of productivity, increasing returns and positive externalities, the "Schumpeterian efficiency standard" is mentioned. According to ECLAC (Economic Commission for Latin America and the 
Caribbean, 2012), Keynesian and Schumpeterian dynamic efficiency tends to present proximity, since the products and sectors that have a greater income elasticity of internal and external demand generally present also innovative characteristics and with high technological content.

Thus, the great challenge facing Brazil is to promote a productive structural change, in order to relative decrease the dependence of its sectors or products with allocative efficiency that are static, without increasing returns to scale, with a low perspective of internal and external income-demand elasticity and low innovative and technological content. Also included in this challenge is to increase production in sectors and products with high technological content, high internal and external income-demand elasticity, with increasing returns to scale and positive feedback in the economy, productivity gains, and growth, enabling, thus, the formation of a virtuous circle of development.

Short-term policies, such as stabilization policies, can interfere in the long term and economic development of a particular country or region. In this manner, studies such as Stiglitz et al. (2006), Ocampo (2005), Rodrick (2013) and Bresser-Pereira (2008) help in the understanding process, as they demonstrate that these relationships can be positive, in the sense of short-term policies positively influencing long-term development, but also could be negative, becoming obstacles to growth and development.

Stiglitz et al. (2006) argue that growth, economic development and stability are central concerns in developed countries and even more relevant in developing economies. Many short-term policy responses can lead to long-term problems. The authors cite that the prescriptions of conservative economists are very contradictory in developing countries. Their recommendations are usually pro-cyclical during recessions. One example was the International Monetary Fund's (IMF) responses to crises in Argentina, South Korea, Thailand, and Indonesia, which advocated strong contractions in fiscal and monetary policies. This is an ironic twist in history, as the IMF was created under the intellectual aegis of John Maynard Keynes, who advocated the use of countercyclical fiscal policies, i.e. to increase spending and reduce taxes, to stimulate the economy during slowdowns and economic development.

The authors explain that developing countries experience more economic volatility than developed ones. In part, this can be explained by the fact that developing economies generally have less productive diversification, so concern for economic stability is particularly relevant. Thus, the challenge is to use stabilization policies that do not harm long-term growth.

According to Stiglitz et al. (2006), the objective of economic policies should be to maximize long-term social welfare in an equitable and sustainable way. To focus on well-being, it is necessary to consider short-term policies that affect long-term growth and development. An important warning is that macroeconomics was conceived in and for industrialized and developed countries. Considering that even in developed countries the results are often flawed when applied in developing economies the consequences may be even more critical. Therefore, the authors conclude that the stabilization policy cannot be separated from the growth policy. If stabilization policies are focused on the wrong objectives and with the use of wrong instruments, they can result in long-term growth and development losses and also raise the level of poverty.

According to Ocampo (2005), the idea that liberalization would lead to rapid economic growth and improvements in living standards in developing countries has been questioned: many of these economies that have undergone liberalizing policies are characterized by macroeconomic vulnerability, low investment rates, increase in international technological gaps and domestic distributive tensions. Most Latin American countries are examples of the economic and social frustrations that structural liberal reforms can bring. Therefore, in this scenario, the author highlights the relevant role of institutions to promote corrections in macroeconomic instability, but with attention to innovation systems and social policies.

One emblematic negative case of short-term policies and variables generating a perverse productive structural change for economic development is the so-called "Dutch disease". According to Bresser-Pereira (2008), the Dutch disease is characterized as a chronic appreciation of the exchange rate resulting from the abundance of natural resources of a particular country or region, which would prevent other tradable goods industries.

Rodrik (2013) argues that the natural resources sector can be thought of as a special type of manufacturing: a sector that converges very rapidly to the global frontier, which uses imported 
technology but has little capacity to absorb labor because it is highly capitalized. More than this, its downstream and downstream links are in most cases weak and would, therefore, produce little spill effect for the rest of the economy. In his study, the author identified that few countries have managed to put their wealth of natural resources to good use in the long run.

\section{Macroeconomic variables in Brazil Territory and innovation}

Several authors such as Erber (2011), Coutinho (2003), Cassiolato and Lastres (2014), Coutinho, Ferraz and Marques (2015), Majumdar (2015), Sagasti (1978) and Katz (1987) argue that the State, through their policies, is fundamental for the development of countries, especially in the formation and maturation of their productive and innovative systems. Initially, the State must ensure that the basic elements of a political and macroeconomic framework are aligned and do promote the country's innovative and productive system. In addition, it must strengthen the productive links, learning processes, creation, and accumulation of productive and innovative capacities. Therefore, it is fundamental to understand the broader role in which the capacities are created, disseminated and necessary in order to contextualize policies with the environment.

The implications of macroeconomic policies for long-term innovation and development policies can occur in a variety of ways. In this respect, Suzigan and Furtado (2006) analyze the Industrial and Foreign Trade Policy (IFTP) and point out the adverse effects of macroeconomic policy: lack of articulation of the instruments and of these with the demands of the companies because of the precarious economic infrastructure, due to inadequacies in the science, technology and innovation (S,T\&I) system; and difficult implementation of IFTP due to the weakness of command and coordination of the industrial policy process, which, consequently, undermined the expected results.

The authors point to some adverse elements that macroeconomics may exert on the industry, innovation, and S, T\&I, such as the adoption of the basic interest rate as the main (and perhaps the only) instrument of action on inflation in the inflation targeting regime (ITR). This can increase the cost of capital by discouraging productive investment and generating large currency volatility with currency overvaluation. Thus, they argue that one of the weaknesses of Brazilian industrial policy and long-term development policies is precisely the action of short-term policies.

Therefore, macroeconomic and microeconomic policies influence firms, the business environment, culture, and all this complex process. Mazzucato and Penna (2016) analyze how economic growth is driven by innovations and argue that innovation policy must consider the nature of the innovative process, which is uncertain, cumulative and cooperative. For this, it must go beyond horizontal policies. Four subsystems are relevant: a) public policies and public financing; b) research and education; c) production and innovation; d) private financing and private funds.

Although all subsystems are of strategic importance, the public policy and financing subsystem have traditionally led the process of socio-economic development and technical changes in international experience. It is crucial that policies are coordinated, so they must have clear diagnoses and prognoses. It is important that there is an "innovative State": this concept encompasses the risk role that the State assumes and was fundamental to success in the few countries that have succeeded in achieving innovation-led growth. Finally, constant dynamic and evaluative monitoring is essential for policies to be improved.

Therefore, for a productive structural transformation to occur in line with Schumpeterian efficiency, a number of elements are necessary for a particular country or region to be able to perform the catching-up. However, an element that is not a sufficient condition, but a necessary one, is precisely the macroeconomic environment that does not compromise innovations.

Mazzucato and Penna (2016) analyze the system of innovations in Brazil and point to the macroeconomic regime as a great weakness. According to the authors, Brazil's macroeconomic policy framework of inflation targets, floating exchange rates, primary surpluses and spending cuts (austerity policies) tends to undermine the effectiveness of industrial policies and innovation. Thus, the macroeconomic tripod has failed to promote economic growth with inflation control, and yet, it also does not promote private investment. The high interest rates and appreciated exchange rates hinder economic dynamism, industry and domestic enterprises. 
According to the authors, the tripod sought to guarantee price stability, public debt / GDP ratio reduction and free monetary policy from the need to promote adjustments in the balance of payments. Thus, in the long run, productive investments would increase. However, Nassif (2015), Lacerda and Loures (2015) and Kregel (2009) argue that the macroeconomic regime was unable to promote price stability and, most importantly, economic growth. Instead of promoting private investment, the tripod has tended to undermine the industrial sector and domestic firms because of high interest rate and appreciated exchange rate, resulting in a low investment rate, compatible with a low-growth.

Another problem is that these high interest rates have created an incentive for the financial and corporate sectors to invest, for example, in government bonds rather than productive infrastructure and innovation assets - which tend to be riskier. In the same way, monetary and exchange rate policy resulted in a trend toward favoring imports, ultimately contributing to the process of deindustrialization, which occurred not only through appreciation of the exchange rate but also through a low level of investment rate and economic growth (SILVA, 2014; LACERDA, LOURES, 2015; SERRANO, SUMMA, 2015).

Melo (2010) analyzes the financing of innovative companies in Brazil and points out that investment in innovation is related to a broader spectrum than merely to the individual decision-making capability of the company, i.e., it incorporates the need for favorable institutional conditions. Thus, fiscal, monetary and exchange rate policies are emphasized and fundamental to the success of innovation policies. In other words, when there is an adverse macroeconomic environment, business expectations are oriented towards investments in activities with less risk than those related to innovation (which are characterized as high risk).

Melo (2010) states that the business investment decision is based on expectations regarding future demand. Therefore, decisions to invest in innovation activities are part of the overall investment strategy of companies. Thus, through this channel, implicit and explicit policies of support for productive investment and innovation can positively or negatively influence this innovative decision-making process. Therefore, in the author's words:

\begin{abstract}
Monetary policy through the interest rate influences the price of the tangible and intangible assets that will be formed through the investment of the companies. It also influences the exchange rate by making it cheaper or more expensive to purchase and acquire machinery and equipment, as well as the purchase and licensing of technology abroad. The monetary policy conducted by the Central Bank also influences expectations regarding future demand behavior for banking and credit regulation. Maintaining a high interest rate for a long time also leads to a preference for financial investment in lower risk public securities than private ones, arbitrage between internal and external financial gains, raising public debt and restricting fiscal spending. The restriction on fiscal spending prevents the government from defining a public sector expenditures policy, which is one of the most effective instruments to support innovation (MELO, 2010, pp. 139-140, our translation).
\end{abstract}

In this context, Viotti (2008) analyzes the evolution and challenges of the Brazilian ST\&I policies: stresses that a monetary policy to combat inflation that is committed solely and exclusively to pursuing the inflation targeting (as the case of the Brazilian ITR) and does not consider in its decisions the fluctuations in the levels of investment, employment and income has had a significant indirect impact on the dynamics of the technological development of companies. This is because, when combined with currency overvaluation and high interest rates, there is a strong negative shock to productive investments, especially in long-term return activities, such as research and development (R\&D) and innovation. The author highlights that this combination of short-term policy has particularly affected companies or the links of productive-chains that are related to activities of high added value.

Seminal works such as those by Dixit and Pyndick (1994) and Fanelli and Frenkel (1996) analyze price stability, investment, and uncertainty. In the first, the authors evidence that the stability and credibility of a given price system and the confidence placed by economic agents in this system is a fundamental determinant of the time horizon and investment uncertainty. Economies with high inflation and/or chronic inflation generate a microeconomic selection of behaviors directed to short-term and high liquidity applications. That is, the opposite of what investments in technology provide. 
Erber (1992) argues that the Latin American countries, including Brazil, are characterized by a credit and capital system marked by the lack of mechanisms that provide companies with resources for investment in technology. It explains that even in those countries that have financial institutions directed to this end, their operational procedures are generally inadequate when considering horizons of long maturation and greater uncertainty.

Bingwen and Huibo (2010) performed a comparative study on national innovation systems in the Brazilian, Russian, Indian and Chinese (BRIC) economies. They argue that macroeconomic conditions are fundamental to the success of the system of innovations. They found that China has been showing relative macroeconomic stability in recent decades, with controlled inflation, low interest rates, and a stable exchange rate. This allows for the creation of a predictable business environment, encouraging domestic and foreign investment. In the same way, India has been presenting, with exception to a financial crisis in 1991, stable macroeconomic conditions. Brazil and Russia are already experiencing macroeconomic instability, which harms investment in innovation.

\section{Empirical model, data and estimation}

In order to investigate the relationships between selected macroeconomic variables and technological innovations, an econometric time series model is estimated in this section. A major challenge in innovation research is the great complexity when finding a proxy variable that represents a country's innovative behavior because innovation has an intangible face and it is difficult to formulate an indicator that measures the wholeness of this phenomenon in its completeness. However, one possible way is to adopt as a proxy for innovation the number of patents deposited in a given period. That is, if a country has a growth in the application for new patents, it is plausible to deduce that the innovations in that region are better than when compared to a reduction in the application for new patents.

Another problem that research of this nature is in Brazil is precisely the scarcity and limitations of data availability. Unfortunately, this reality is aggravated, especially when it comes to innovations. Nevertheless, it was possible to compose a reliable and robust sample of data. For this purpose, a database is adopted that covers the period from January 2009 to December 2016, totaling 96 observations. This period is relevant because it reflects the current situation and eliminates distortions in the series resulting from the large volatilities of the indicators in the 2007-2008 crisis, mainly in terms of heteroscedasticity, autocorrelation and other econometric problems that compromise the results of the model. The software used is Eviews 9.0 and Gretl (C).

After reviewing the literature, with the keywords related to the subject in Portuguese and English, in the full access to the periodical portal of the Coordination of Improvement of Higher Education Personnel (CAPES), which has a collection of more than 53 thousand periodicals with full texts and 129 reference bases of important national and international scientific productions, few studies of this nature were found. Therefore, the innovative and exploratory nature of this work is emphasized.

The investigative approach seeks to observe the relationships between new patent applications and selected macroeconomic variables in order to see if they have positive or negative relationships to innovation. To this end, the innovation proxy is represented by applications for new patents issued by residents registered with the National Institute of Industrial Property (INPI), published by the Ministry of Science, Technology, Innovation and Communications (MCTIC). The selected macroeconomic variables are four: exchange rate, interest rate, inflation rate, and industrial production. The exchange rate refers to the US dollar, purchase value, average of the period, published by the Central Bank of Brazil (BCB); the interest rate corresponds to the SELIC, rate over, disclosed by the BCB; Inflation refers to the broad consumer price index (IPCA), derived from IBGE; and, finally, total industrial production was obtained at $\mathrm{BCB}$. All variables were transformed into an index based on the average referential base of 2010. The periodicity is monthly, with an exception for patent applications that have an annual sample.

Thus, the frequency of the patent series was adjusted from annual to monthly, in order to allow a greater amount of observations and, in this way, increase the degrees of freedom of the model - i.e., the difference between the number of observations of the sample and the number of explanatory variables. In order to perform the adjustment, the interpolation process was performed. This process is an econometric/statistical procedure to obtain monthly data from annual data. There are different methods 
for performing an interpolation: Friedman (1962) proposes the use of related series in the interpolation process; Chow and Lin (1971), however, construct an estimator, considering the best-unbiased estimator to perform the interpolation.

In order to perform the interpolation, Gretl $(\subset)$ software was used, considering the method of Chow and Lin (1971). The annual variable had its annual value divided by 12 to capture the monthly average, and from this monthly average, the interpolation was performed, creating the monthly observations from this annual value. It should be noted that, given the characteristics of the interpolation estimator method, the long-term average (annual value) is not impaired, and there is no bias in the econometric estimation when considering longer terms (which is the case of this study).

The objective of the estimation is to investigate the impulse-response effect of positive shocks on selected macroeconomic variables in relation to innovation. That is, what will be the response of the innovation proxy if there is a depreciation of the exchange rate, a rise in the interest rate, a rise in industrial production and an increase in inflation. The benchmark model is expressed in equation (1), in which represents the innovations, is the exchange rate, is the interest rate, is inflation and is the error-term.

(1) $\mathbb{N}=\mathrm{E}+\mathrm{i}+\mathrm{Y}+\pi(\mathrm{i})+\mathrm{e}$

As a hypothesis, we expect negative relations of innovation with interest and inflation, as well as a positive relation with industrial production, exchange and with the own innovation (i.e., evidencing a persistence-effect in time of innovations).

\section{Unit root test}

First, to verify if the variables follow a steady stochastic process, the Augmented Dickey-Fuller (ADF) and the Phillip-Perron (PP) unit root tests were performed. Table 1 shows the results of the ADF test for the series and their first difference, in which the null hypothesis of the test (H0) is that the series has a unit root - i.e., it is non-stationary. Most of the variables have an intercept, with the exception of the exchange rate, which has a trend and an intercept.

\begin{tabular}{c|ccccc}
\hline Variables & cambio & i & INPI & IPCA & Prodind \\
Terms & T, I & I & I & I & I \\
t Statistic & -2.745535 & -2.379864 & -2.074660 & -4.228410 & -0.616688 \\
\hline Critical Values & & & & & \\
$1 \%$ & -4.058619 & -3.502238 & -3.507394 & -3.500669 & -3.501445 \\
$5 \%$ & -3.458326 & -2.892879 & -2.895109 & -2.892200 & -2.892536 \\
$10 \%$ & -3.155161 & -2.583553 & -2.584738 & -2.583192 & -2.583371 \\
\hline Variables & dcambio & di & dINPI & dIPCA & dProdind \\
Terms & T, I & I & I & I & I \\
t Statistic & -6.427590 & -3.989340 & -3.596725 & -10.35652 & -11.50285 \\
\hline Critical Values & & & & & \\
$1 \%$ & -4.058619 & -3.503879 & -3.507394 & -3.501445 & -3.501445 \\
$5 \%$ & -3.458326 & -2.893589 & -2.895109 & -2.892536 & -2.892536 \\
$10 \%$ & -3.155161 & -2.583931 & -2.584738 & -2.583371 & -2.583371 \\
\hline
\end{tabular}

Table 1 - Unit root test at the level and first differences: Augmented Dickey-Fuller. Source: Authors own using Eviews 9.0.

The results indicate that the variables cambio (exchange rate), i (interest rate), INPI (innovation) and Prodind (industrial production) variables are not stationary at $5 \%$ of statistical significance, but when tested in the first difference, all were stationary. Also, the IPCA (inflation rate) was stationary at the level.

The results of the PP test indicate the same conclusions of the ADF, i.e., the variables are not stationary at $5 \%$ of statistical significance at the level but when tested in the first difference, all variables were stationary, apart from IPCA, which was stationary in level. After the unit root tests, the next topic reveals the analysis of the lag tests of the models. 


\begin{tabular}{c|ccccc}
\hline Variables & cambio & i & INPI & IPCA & Prodind \\
Terms & T, I & I & I & I & I \\
t Statistic & -2.745535 & -2.379864 & -2.074660 & -4.228410 & -0.616688 \\
\hline Critical Values & & & & & \\
$1 \%$ & -4.058619 & -3.502238 & -3.507394 & -3.500669 & -3.501445 \\
$5 \%$ & -3.458326 & -2.892879 & -2.895109 & -2.892200 & -2.892536 \\
$10 \%$ & -3.155161 & -2.583553 & -2.584738 & -2.583192 & -2.583371 \\
\hline Variables & dcambio & di & dINPI & dIPCA & dProdind \\
Terms & T, I & I & I & I & I \\
t Statistic & -6.427590 & -3.989340 & -3.596725 & -10.35652 & -11.50285 \\
\hline Critical Values & & & & & \\
$1 \%$ & -4.058619 & -3.503879 & -3.507394 & -3.501445 & -3.501445 \\
$5 \%$ & -3.458326 & -2.893589 & -2.895109 & -2.892536 & -2.892536 \\
$10 \%$ & -3.155161 & -2.583931 & -2.584738 & -2.583371 & -2.583371 \\
\hline
\end{tabular}

Table 2 - Unit root test at the level and first differences: Phillips-Perron. Source: Authors own using Eviews 9.0.

\section{Optimal lag number test}

After analyzing the stationarity of the series, it is important to investigate how many lags are optimal, i.e., how many lags fit the model better. Table 3 shows the tests.

\begin{tabular}{ccccccc}
\hline Lag & LogL & LR & FPE & AIC & SC & HQ \\
\hline \hline 0 & -1231.659 & NA & 1528145. & 28.42895 & 28.57066 & 28.48601 \\
1 & -1143.093 & 164.9167 & 354818.2 & 26.96765 & $27.81796^{*}$ & 27.31004 \\
2 & -1102.766 & 70.45642 & 250877.9 & 26.61530 & 28.17421 & $27.24303^{*}$ \\
3 & -1084.833 & 29.26897 & 299406.5 & 26.77778 & 29.04528 & 27.69083 \\
4 & -1052.384 & 49.23292 & 259300.0 & 26.60654 & 29.58263 & 27.80492 \\
5 & -1005.580 & $65.63316^{*}$ & $164386.4^{*}$ & $26.10530^{*}$ & 29.78999 & 27.58901 \\
6 & -989.6119 & 20.55707 & 216853.9 & 26.31292 & 30.70620 & 28.08196 \\
7 & -962.1665 & 32.17742 & 226653.7 & 26.25670 & 31.35858 & 28.31107 \\
8 & -931.5261 & 32.40132 & 229108.9 & 26.12704 & 31.93751 & 28.46674 \\
\hline
\end{tabular}

Table 3 - Model's optimal lag number test. Source: Authors own using Eviews 9.0.

The tests presented in Table 3 indicate that the optimal lag number that fit the model would be one, two, and five. These indicative tests and the two lags model shown to be more adjusted. Once the lags of the models have been tested, the next step is to analyze the cointegration.

\section{Cointegration test}

It is relevant to perform a Johansen cointegration test with the purpose of ascertaining whether a linear combination of these variables is stationary, thus indicating that there is a long-term relationship between them. The results can be seen in Table 4 .

\begin{tabular}{|c|c|c|c|c|}
\hline \multicolumn{5}{|c|}{ Unrestricted cointegration rank test (maximum eigenvalue) - Brazil } \\
\hline Hypothesized & & Max-Eigen & 0.05 & \\
\hline No. of CE(s) & Eigenvalue & Statistic & Critical value & Prob.** \\
\hline None * & 0.314295 & 35.08965 & 34.80587 & 0.0462 \\
\hline At most 1 & 0.212826 & 22.25549 & 28.58808 & 0.2600 \\
\hline At most 2 & 0.138426 & 13.85647 & 22.29962 & 0.4752 \\
\hline At most 3 & 0.039111 & 3.710390 & 15.89210 & 0.9704 \\
\hline At most 4 & 0.012615 & 1.180665 & 9.164546 & 0.9263 \\
\hline
\end{tabular}

Table 4 - Johansen cointegration test. Source: Authors own using Eviews 9.0.

Analyzing Johansen's cointegration tests by the maximum value, it can be observed that there is evidence of a long-term relationship in the model. In this case, the adoption of the error vector error 
correction (VEC) model is implied. The VEC model will be estimated with a cointegration equation, as indicated by the test.

\section{Autocorrelation and heteroskedasticity tests}

In order to confirm if the models were well specified, it is interesting to perform the residual autocorrelation test (VAR residual serial correlation LM tests). The null hypothesis of this test is that there is no serial autocorrelation in the model residuals. Thus, non-rejection of the null hypothesis indicates that there is no autocorrelation in the regressors residues. These values can be seen in Table 5 .

\begin{tabular}{ccc}
\hline Lags & LM-Stat & Prob \\
\hline 1 & 21.04987 & 0.6898 \\
2 & 34.40690 & 0.0995 \\
3 & 48.33685 & 0.0034 \\
\hline
\end{tabular}

Table 5 - Residual autocorrelation. Source: Authors own using Eviews 9.0.

Analyzing the results shown in Table 5, it can be noted that there is no evidence for rejection of the null hypothesis (no serial autocorrelation), indicating that there is no autocorrelation in the residues. Therefore, the next step is to analyze the heteroscedasticity of the residues, presented in Table 6.

\begin{tabular}{cc|c}
\hline \multicolumn{3}{c}{ Brazil } \\
\hline Chi-sq & $\mathrm{df}$ & Prob. \\
363.6070 & 330 & 0.0982 \\
\hline
\end{tabular}

Table 6 - Heteroscedasticity test. Source: Authors own using Eviews 9.0.

The result of Table 6 gives evidence of the non-presence of heteroscedasticity of the residues. Upon reaching a probability greater than $5 \%$, it is possible to conclude that there is no heteroscedasticity and autocorrelation of residues. In this way, as evident by the tests, the models used in the study are well specified and do not have any of these problems.

\section{Analysis of the results}

The impulse-response function allows the observation of the reaction of the variables of a given system when a given variable is given a shock over a time horizon, thus allowing the analysis of these interrelationships1. Thus, in Figure 1, it can be seen how the innovation proxy responds to a positive shock in itself, in the exchange rate (exchange rate depreciation), in interest rates (SELIC increase), inflation (high of the IPCA) and in industrial production (production growth). 
Response to Cholesky One S.D. Innovations

Response of INPI to INPI

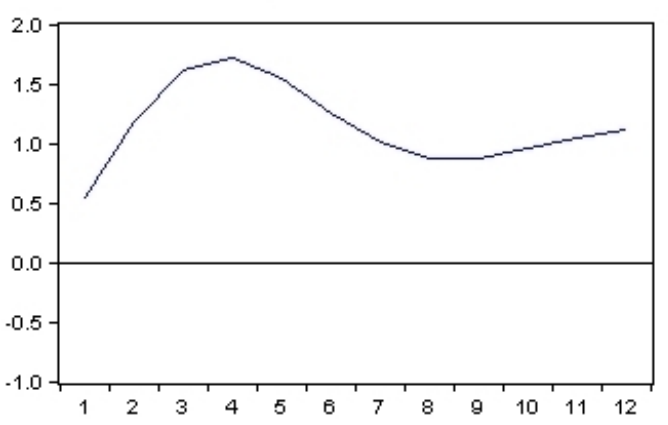

Response of INPI to I

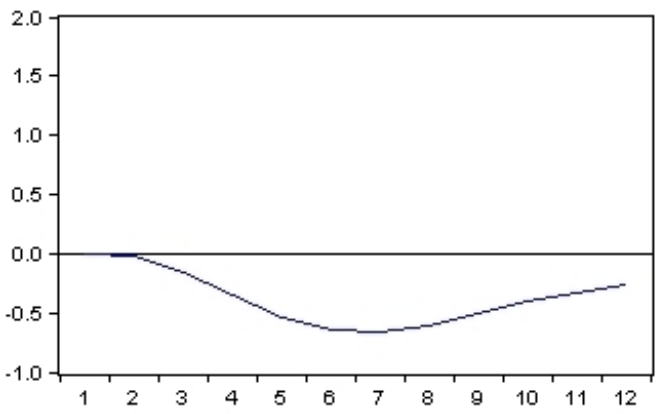

Response of INPI to IPCA

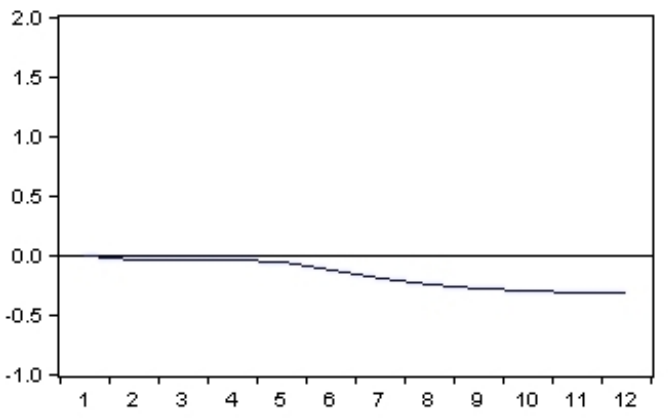

Response of INPI to CAMBIO

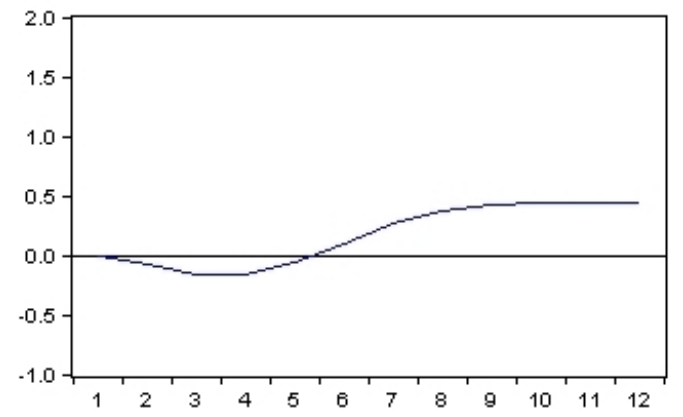

Response of INPI to PIND

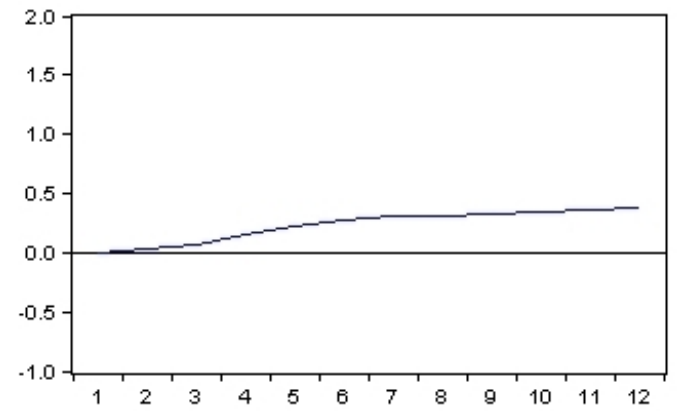

Figure 1 - Response of innovation proxy of an innovation (shock) in innovation, exchange rate, interest rate, industrial production, and inflation rate. Source: Authors own using Eviews 9.0.

Innovations, i.e., applications for new patents per residents in the INPI, respond positively to a shock in itself. This means that raising innovation tends to help raise innovation itself. But the response to a currency depreciation tends to have a slightly negative, short-term, and positive effect after five periods, so perhaps a depreciation causes short-term instabilities, but, once the volatilities pass, it positively helps innovation. A monetary tightening represented by the rise in interest rates tends to negatively impact innovations, probably because it is a measure of contraction of economic activity and because it represents a rise in the costs of innovative activity financing. The growth of industrial production tends to aid innovation by having a positive relationship, that is, a greater dynamism of industrial production tends to be beneficial for innovations. Finally, when there is a rise in inflation, after passing some periods there is a negative impact on innovation, then higher inflation probably reflects a more unstable economic scenario and undermines innovations and long-term planning, to which many innovations are related. In Figure 2, one can observe the accumulated responses.

By the analysis of Figure 2, which presents the accumulative response of innovation to a positive shock in the variables of innovation, exchange rate, interest rate, industrial production, and inflation rate, 
we can observe: a negative relation between innovation and macroeconomic interest variables and inflation; a positive relationship with industrial production and with innovation itself; and a subtly negative relationship with short-term currency depreciation, but becoming positive after some periods.

The results are, in general, in line with the arguments of several authors specialized in innovation. Mazzucatto and Pena (2016) point out that the high interest rates and appreciated exchange rates hinder economic dynamism, industry, domestic enterprises and, consequently, innovations. Suzigan and Furtado (2006) also point in the same direction, claiming that an increase in interest rates may increase the cost of capital by discouraging productive investment and generating large currency volatility with currency overvaluation. Kregel (2009), Silva, (2014), and Serrano and Summa (2015) analyze the macroeconomic regime in Brazil. One problem that may occur is that high interest rates create an incentive for the financial and corporate sectors to invest in government securities rather than productive assets of infrastructure and innovation, for example, which tend to be riskier. Moreover, an appreciated exchange rate tends to result in a low rate of investment and growth.

\section{Accumulated Response to Cholesky One S.D. Innovations}

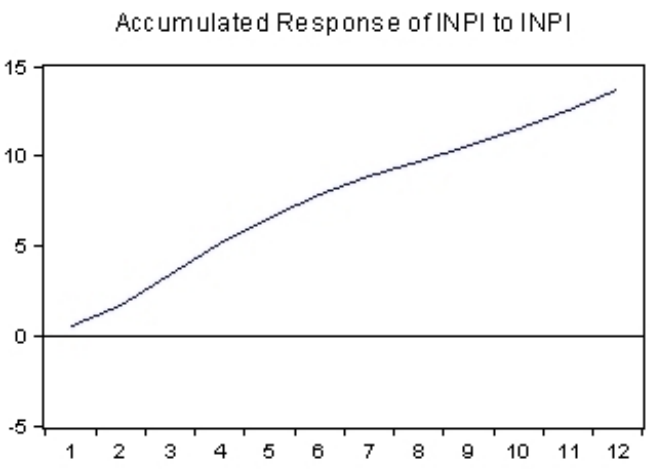

Accumulated Response of INPI to CAMBIO

Accumulated Response of INPI to I

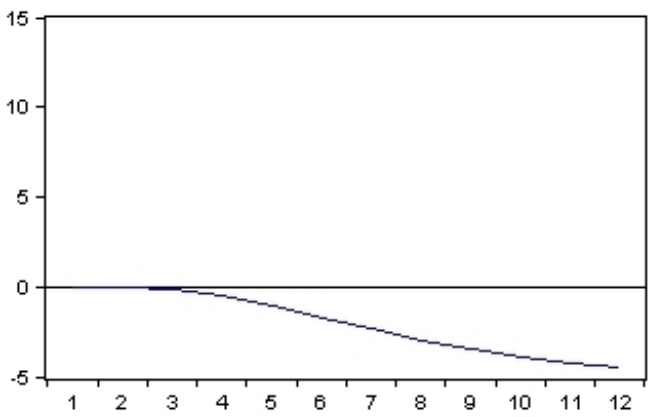

Accumulated Response of INPI to IPCA

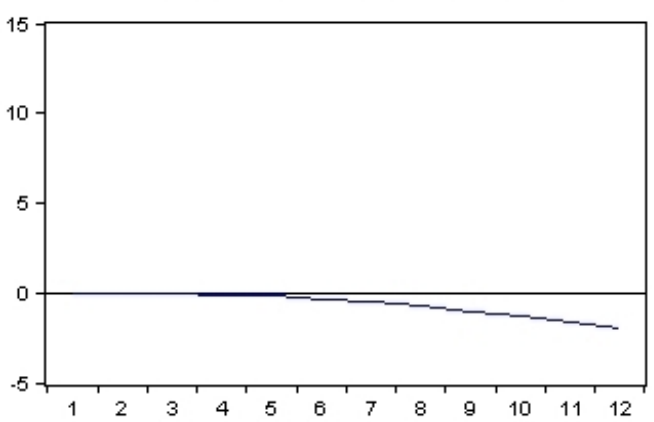

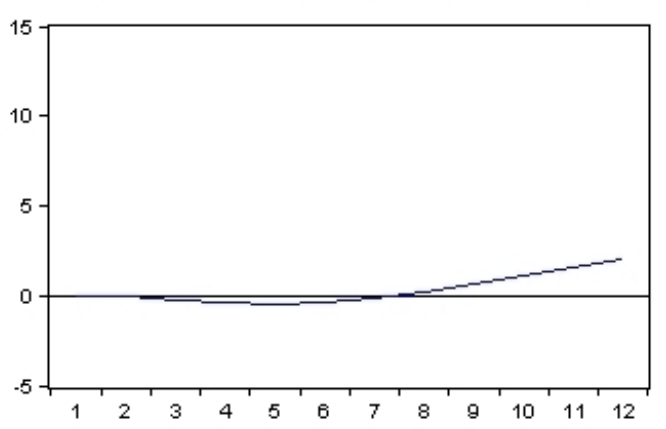

Accumulated Response of INPI to PIND

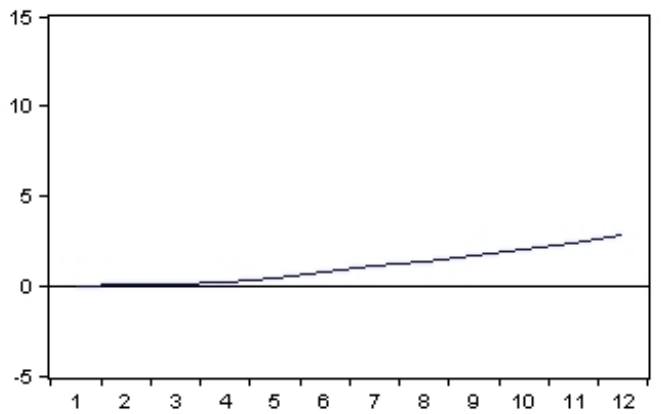

Figure 2 - Accumulated Response of innovation proxy of an innovation (shock) in innovation, exchange rate, interest rate, industrial production, and inflation rate. Source: Authors own using Eviews 9.0. 
In relation to inflation, Dixit and Pyndick (1994) and Fanelli and Frenkel (1996) argue that economies with high inflation and/or chronic inflation generate a microeconomic behavior selection directed toward short-term and high liquidity applications. That is, the opposite of what investments in technology provide. Therefore, these results indicate that it is important to consider macroeconomic policies when formulating innovation policies.

After verifying the relevance of the relations among macroeconomic variables and tecnological innovations, it is important to discuss public policies interventions. It is evidente that public policies are necessary to promoto innovations in a particular country or region. In this context, coordination between short run policies (related with macroeconomic variables) and long run policies (e.g. industrial and technological policies) are important.

In the meantime, industrial policiy discussions gained extreme relevance. According to Erber (1992) and Coutinho and Ferraz (1994), an industrial policy can be conceived as a set of coordinated action stratedies, either public or private, usually focusing on promoting industrial development. Nevertheless, despite of the initial concept being conected to the manufacture sector, nowadays there are no limits to these incentives, which could be directed to "any"estrategical sector for the nation or region. Generally the literature presentes two policy strands, the horizontal and the vertical ones. Horizontal policies are broader and not sector or chain-specific; verfical ones, however, are specific. The latter prioritize sectors and supply chains for policies implementation.

Analyzing central countries action toward policies fostering innovation systems, Erber (1980) argues that there are three main indications. First, that State action reforce and criates positive interferences in the cientifical and technological prcesso, given the capital accumulation and the labour division. Second, this State measures in central countries outweigh a meare support to R\&D activities. Third, the support is directed toward so called high-end industries, with higher technological contect. The author indicate that in countries with characteristics of Latin American ones. Such as Brazil, these policies are even more importante, because:

(...) bachwardness situations in uderdeveloped countries are characterized by the absence of central linkages in the productive and institutional structure, which require a structured action of the State to induce - or even to assume the direct responsibility by state enterprises - the assembly of certain sectors in the productive matrix, involving a radical rupture of pre-existing routines. (ERBER, 1992, p. 16-17, our translation.)

This is largely because in central nations it was necessary the creation of capacities in activities such as capital goods industry and the electronical complex. Therefore, it is evident the extreme relevance of short and long run policies to elevate the chances of success in the technological development process.

\section{CONCLUSIONS}

This study aimed to analyze the relationships between selected macroeconomic variables and innovations. In general, as a result, a negative relationship between innovation and the macroeconomic variables of interest and inflation rates was found, a positive relationship with industrial production and with the innovation itself and a subtly negative relationship with a short-term exchange depreciation, but becoming positive after passing some periods.

Therefore, the results follow the arguments of several authors specialized in innovation, such as Mazzucatto and Pena (2016), Suzigan and Furtado (2006), Melo (2010), Viotti (2008), Erber (1992), Bingwen and Huibo 2010), among others. We conclude that increases in the basic interest rate tend to be detrimental to innovation activities, probably because of the contractionary effect of this policy, but also because of the higher costs of financing the innovations. The instabilities of an acceleration in inflation also tend to undermine innovations: this more unstable scenario is likely to undermine the long-term planning to which many innovations are related. The growth of industrial production is important in stimulating innovation, probably because a greater dynamism of this sector tends to favor and impel new products, processes, and innovations. Finally, a depreciation of the exchange rate tends to generate instabilities in the short term, and possibly because of this, in the short term, the response of the 
innovations has been slightly negative in relation to the depreciation in the exchange rate. However, after this initial period, a positive relation in innovation occurs.

In short, technological innovations are a complex phenomenon that has several nuances and particularities. It was not the intention of this paper to summarize a process so complex with its relations with the macroeconomic variables. However, the results give evidence that macroeconomic variables may be important to aid the country's innovative process. Finally, it is important to consider these variables when formulating innovation policies.

Therefore, a major contribution of this study was the demonstration by an econometric model the relationship among macroeconomic variables and thecnological innovations. This contribution, considering its format, period of analysis and method has a great novelty in the literature. Thus, this study can serve as a foundation or inspiration for several new investigations for other regions and countries, as well as for the adoption of new methods and samples.

\section{REFERENCES}

BINGWEN, Z.; HUIBO, Z. Estudo comparativo sobre sistemas nacionais de inovação nas economias BRIC. Revista Tempo do Mundo, Brasília, v. 2, n. 2, p. 119-147, ago. 2010.

BRESSER-PEREIRA, L. C. Doença holandesa e sua neutralização: uma abordagem ricardiana. In: 47-71.

(Org.). Doença holandesa e a indústria. Rio de Janeiro: Fundação Getúlio Vargas, 2008. p.

CASSIOLATO, J. E.; LASTRES, H. M. M. Inovação e desenvolvimento: a força e permanência das contribuições de Erber. In: PRADO, L. C. D.; LASTRES, H. M. M. (Org.). Estratégias de desenvolvimento, política industrial e inovação: ensaios em memória de Fábio Erber. Rio de Janeiro: Banco Nacional de Desenvolvimento Econômico e Social, 2014. p. 379-414.

COUTINHO, L. e FERRAZ, J. C. Estudo da Competitividade da Indústria Brasileira, síntese final, Campinas: Papirus; FUCAMP, Universidade Estadual de Campinas, 1994.

CHOW, G. C.; LIN, A. Best linear unbiased interpolation, distribution, and extrapolation of time series by related series. The Review of Economics and Statistics, v. 53, n. 4, p. 372-375, Nov. 1971.

COMISIÓN ECONÓMICA PARA AMÉRICA LATINA Y EL CARIBE. Cambio estructural para la igualdad: una visión integrada del desarrollo. Santiago, Chile: Nações Unidas, 2012. Available at: . Acesso em: 10 maio 2018.

COUTINHO, L. Macroeconomic regimes and business strategies: an alternative industrial policy for Brazil in the wake of the 21 st Century. In: CASSIOLATO, J. E.; LASTRES, H. M. M.; MACIEL, M. L. (Eds.). Systems of innovation and development: evidence from Brazil. Cheltenham, UK: Edward Elgar, 2003. p. 311-328.

COUTINHO, L.; FERRAZ, J. C; MARQUES, F. S. Development, uncertainty and the role of state investment banks. In: MAZZUCATO, M.; PENNA, C (Eds.). Mission-oriented finance for innovation: new ideas for investment-led growth. Westminster; London: Policy Network; Rowman \& Littlefield International, 2015. p. 97-104.

DIXIT, A.; PYNDICK, R. Investment under uncertainty. Princeton: Princeton University Press, 1994.

DOSI, G. Technological paradigms and technological trajectories: a suggested interpretation of the determinants and directions of technical change. Research policy, v. 11, n. 3, p. 147-162, June 1982.

DOSI, G.; FREEMAN, C.R.; NELSON, R.R.; SOETE, L. Technical change and economic theory. London: Pinter Publishers, 1988.

DOSI, G.; PAVITT, K.; SOETE, L. The economics of technical change and international trade. New York, NY, US: New York University Press, 1990.

ERBER, F. Desenvolvimento tecnológico e intervenção do Estado: um confronto entre a experiência 
brasileira e a dos países centrais. Revista de Administração Pública, v. 14, n. 4, 1980.

As convenções de desenvolvimento no governo Lula: um ensaio de economia política. Revista de Economia Política, São Paulo, v. 31, n. 1, p. 31-55, jan./mar. 2011.

Desenvolvimento industrial e tecnológico na década de 90: uma nova política para um novo padrão de desenvolvimento, Ensaios FEE, Porto Alegre, v. 13, n. 1, p. 9-42, 1992.

FANELLI, J.; FRENKEL, R. Estabilidad y estructura: interacciones en el crecimiento económico. In: KATZ, J. M. (Ed.). Estabilización macroeconómica, reforma estructural y comportamiento industrial: estructura y funcionamiento del sector manufacturero latinoamericano en los años 90. Buenos Aires: Alianza Editorial, 1996. p. 21-79.

FRIEDMAN, M. The interpolation of time series by related series. Journal of the American Statistical Association, v. 57, n. 300, p. 729-757, 1962.

KATZ, J. Technology generation in Latin American manufacturing industries: theory and case-studies concerning its nature, magnitude and consequences. London: Macmillan, 1987.

KREGEL, J. The global crisis and the implications for developing countries and the BRICs: is the "B" really justified? Revista de Economia Política, São Paulo, v. 29, n. 4, p. 341-356, 2009.

LACERDA, A. C.; LOURES, R. Para o Brasil evitar o risco da desindustrialização. In: BARBOSA, N. et al. (Orgs.). Indústria e desenvolvimento produtivo no Brasil. Rio de Janeiro: Elsevier, 2015. p. 153-169.

MAJUMDAR, A. Why we need public endowments for transformative research. In: MAZZUCATO, M.; PENNA, C. (Eds.). Mission-oriented finance for innovation: new ideas for investment-led growth. Westminster; London: Policy Network; Rowman \& Littlefield International, 2015. p. 59-65.

MAZZUCATO, M.; PENNA, C. The Brazilian innovation system: a mission-oriented policy proposal. Avaliação de Programas em CT\&I. Apoio ao Programa Nacional de Ciência (plataformas de conhecimento). Brasília, DF: Centro de Gestão e Estudos Estratégicos, 2016. Available at: . Acesso em: 10 maio 2018.

MELO, L. M. O financiamento das empresas inovadoras: alternativas para discussão. Revista Economia \& Tecnologia, Curitiba, v. 6, n. 1, p. 139-147, 2010.

NASSIF, A. As armadilhas do tripé da política macroeconômica brasileira. Revista de Economia Política, São Paulo, v. 35, n. 3, p. 426-443, jul./set. 2015.

OCAMPO, J. A. Beyond reforms: structural dynamics and macroeconomic vulnerability. [S. 1.]: Stanford University Press; The World Bank, 2005.

RODRIK, D. The past, present and future of economic growth. [S. 1.], 2013. (Global Citizen Foundation Working Paper 1, June, 2013). Available at: .

SAGASTI, F. Science and technology for development: main comparative report of the Science and Technology Policy Instruments Project. Ottawa, Canada: International Development Research Centre, 1978. Available at: . Acesso em: 24 abr. 2018.

SCHUMPETER, J. A. A teoria do desenvolvimento econômico. São Paulo: Abril Cultural, 1982.

SERRANO, F.; SUMMA, R. Aggregate demand and the slowdown of Brazilian economic growth in 2011-2014. Nova Economia, Belo Horizonte, v. 25, n. especial, p. 803-833, dez. 2015.

SILVA, J. A. Desindustrialização e doença holandesa: o caso brasileiro. Indicadores Econômicos FEE, Porto Alegre, v. 41, n. 3, p. 67-82, 2014.

STIGLITZ, J.; OCAMPO, J.; NAYYAR, D.; FFRENCH-DAVIS, R.; SPIEGEL, S. Stability with growth: macroeconomics, liberalization and development. Oxford: Oxford University Press, 2006.

SUZIGAN, W.; FURTADO, J. Política industrial e desenvolvimento. Revista de Economia Política, São 
Paulo, v. 26, n. 2, p. 163-185, abr./jun. 2006.

VIOTTI, E. B. Avaliação de políticas de ciência e tecnologia e inovação: diálogo entre experiências internacionais e brasileira. Brasília: CGEE, 2008.

\section{APPENDIX}

Normalized cointegrating coefficients (standar error in parentheses):

$$
\begin{aligned}
& \widehat{I N P I}_{1, t}=507,7922-0,677704 \text { CAMBIO }_{t}-0,509091 I_{t}-5,0197 \text { PIND }_{t}+0,074159 \text { IPCA }_{t}
\end{aligned}
$$

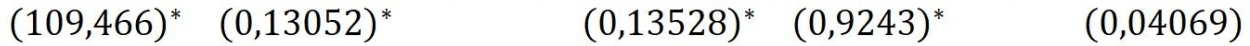

\section{(2)}

Note: The asteristics $(*)$ refer to statistical significance at $1 \%$.

In a summary, long run shocks in the exchange rate (cambio), interest rate (i), industrial production (pind) variables are incorporated in the technological innovation generation (inpi), since these variables present statistical significance. 